\title{
Protein TSSC1
}

National Cancer Institute

\section{Source}

National Cancer Institute. Protein TSSC1. NCI Thesaurus. Code C21245.

Protein TSSC1 (387 aa, $44 \mathrm{kDa}$ ) is encoded by the human EIPR1 gene. This protein may be involved in vesicular trafficking. 